Acta vet. scand. $1976,17,244-254$.

From the Department of Microbiology and Immunology, Veterinary

College of Norway, Oslo.

\title{
THE APPLICABILITY OF AGAR-DIFFUSION TEST IN MEASURING DEOXYRIBONUCLEASES IN PIG INTESTINAL CONTENT
}

By

Eivind Liven

\begin{abstract}
LIVEN, EIVIND: The applicability of agar-diffusion test in measuring deoxyribonucleases in pig intestinal content. Acta vet. scand. $1976,17,244-254$. - The suitability of an agar-diffusion test (ADT) using toluidine blue deoxyribonucleic acid agar (TDA) for measuring DNase activity in pig intestinal contents was investigated. The ADT was compared with a spectrophotometrical method. Distinct metachromatic zones around wells in the DNA-containing agar, into which the intestinal content was applied, indicated DNase activity. The DNase activity was determined semiquantitatively by making serial twofold dilutions of the intestinal content. The spectrophotometrical method was optimal at $\mathrm{pH}$ 7.2. The ADT proved to be most sensitive at $\mathrm{pH}$ 5.6. The ability of the 2 methods employed to measure low concentrations of DNases was equal. However, the ADT was considered more suitable than the spectrophotometrical method because ADT measured reduced amounts of enzyme. DNase activity was demonstrated throughout the small intestine and in the large intestine. By the zymogram technique, at least 3 different DNases could be demonstrated in the lower parts of the small intestine, 1 of which could be of extrapancreatic origin.
\end{abstract}

agar-diffusion; deoxyribonucleases; pig intestin a l c on tent.

Interest in the use of single cell proteins in animal, and also human, diets has increased in recent years. Single cell proteins usually contain large amounts of nucleic acids (Kihlberg 1972). Man and birds metabolize nitrogen-containing components such as nucleic acids to ureates. When present in high concentrations, ureates may precipitate in various organs, a phenomenon which, because of different metabolic pathways only occurs in the species mentioned above. In connection with this, it would be of considerable interest to study the concentrations and activity of 
deoxyribonucleases (DNases) in the intestines of various types of animals fed single cell proteins. However, before submitting animals fed on single cell proteins to these enzyme measurements, it was considered necessary to find an appropriate method.

As reviewed by Laskowski (1961), various methods have been applied for determining DNase activity in tissue components of animal origin. None of these seemed to be based on the principle of agar-diffusion. Measurements of DNase activity of microbial origin, however, have been performed using the agar-diffusion test (ADT) (Lachica et al. 1971, Porschen \& Sonntag 1974, Sandvik 1974, Liven 1975). Considering the complexity of the methods reviewed by Laskowski compared to ADT, the aim of the present work was primarily to elucidate whether the ADT could be employed in measuring DNase activity also in intestinal contents. It was regarded as useful to compare the ADT with spectrophotometrical measurements. Secondly it was of interest to find out whether different fractions of DNase activity in intestinal contents could be separated employing the zymogram technique.

\section{MATERIALS AND METHODS}

\section{Intestinal contents}

Intestinal contents were collected randomly from slaughter pigs in connection with the slaughtering process. The contents were diluted 1:3 in distilled water and centrifuged at $16000 \times \mathrm{g}$ for $10 \mathrm{~min}$. The supernatants were dialysed against running water for $18 \mathrm{hrs}$. and stored at $-20^{\circ} \mathrm{C}$. This treated intestinal content is designated prepared intestinal content (PIC). A total of about 30 samples were collected from 6 pigs from the duodenum, the upper, middle and lower part of the jejunum and from the middle part of the colon.

\section{Assay of DNase activity employing ADT}

Due to the requirements of DNases present in the pancreatic juice for magnesium ions, toluidine blue deoxyribonucleic agar (TDA) (Lachica et al. 1971) was modified by replacing 0.01 $\mathrm{M}-\mathrm{CaCl}_{2}$ with $0.01 \mathrm{M}-\mathrm{MgSO}_{4}$. The $\mathrm{pH}$ of the TDA medium was adjusted to $4.0,5.0,5.6,7.2,8.0$ and 9.0 by replacing the Tris

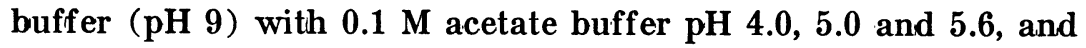
$0.1 \mathrm{M}$ Tris-HCl buffer $\mathrm{pH} 7.2,8.0$ and 9.0. The media were 
poured into glass trays to a depth of $2 \mathrm{~mm}$ and allowed to solidify. Circular wells of $7 \mathrm{~mm}$ diameter in the TDA media were filled with aliquots of $0.05 \mathrm{ml}$ PIC. Controls were run by applying distilled water into corresponding wells in TDA, and by using the procedure with PIC on TDA without DNA incorporated. Similarly, due to the inhibition of DNases in pancreatic juice by high concentrations of $\mathrm{NaCl}$ and their requirements for magnesium ions (Laskowski 1961), it was considered advantageous to observe the effect of PIC upon TDA containing $2 \mathrm{M}-\mathrm{NaCl}$, and upon TDA without $\mathrm{MgSO}_{4}$.

In onder to obtain a semi-quantitative measure of the DNase concentration, serial twofold dilutions of PIC were prepared in distilled water. The dilutions were applied into wells in the TDA medium optimal for detecting DNases in PIC, and the titres of the DNases were determined. Using this procedure the number of diffusion units in the sample and the sensitivity of the ADT were determined according to Sandvik (1962) and Dahle (1969).

The TDA-plates were incubated at $37^{\circ} \mathrm{C}$ for $20 \mathrm{hrs}$. after application of the PIC. The presence of DNases in PIC was seen as pink circular zones in the otherwise blue medium.

\section{Assay of DNase activity using spectrophotometry}

In this procedure the principles outlined by McDonald (1955) were followed. One $\mathrm{ml}$ substrate ${ }^{\star}$ was mixed with $1 \mathrm{ml}$ buffer and $1 \mathrm{ml}$ enzyme-containing material (PIC) and incubated at $37^{\circ} \mathrm{C}$ in a water bath for $30 \mathrm{~min}$. The reaction was interrupted by adding $1 \mathrm{ml} 5 \%$ trichloracetic acid (TCA). Controls were run in each experiment by adding the enzyme after the addition of TCA. The solutions were centrifuged at $48000 \times \mathrm{g}$ for $15 \mathrm{~min}$. and the absorbance of the supernatants and their twofold dilutions in distilled water were measured at $260 \mathrm{~nm}$ with the controls as blanks. The buffers used in the ADT were also used in this method. At the $\mathrm{pH}$ value showing the highest activity, serial twofold dilutions in distilled water of PIC were performed in order to determine the highest dilution at which DNase activity could still be detected.

* $150 \mathrm{mg}$ DNA (Difco)

$50 \mathrm{ml} 0.01{\mathrm{M}-\mathrm{MgSO}_{4}}$ $50 \mathrm{ml}$ distilled water.

(The DNA is dissolved at $100^{\circ} \mathrm{C}$ for $5-10 \mathrm{~min}$.). 


\section{Zymograms}

The protein fraction of the PIC was precipitated by adding $\left(\mathrm{NH}_{4}\right)_{2} \mathrm{SO}_{4}$ to $80 \%$ saturation. The precipitate was suspended in an equal volume of distilled water, and dialysed against running water for $18 \mathrm{hrs}$. The principles of the zymogram technique used is described by Dahle (1970). Gel-electrophoresis of the precipitated protein was carried out using $1 \%$ agar (Difco*, Special Noble-agar 0142-01) in 0.1 $\mathrm{M}$ acetate buffer, pH 5.6. Agar gels were poured onto microscope slides and the electrophoresis run

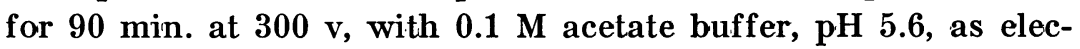
trode buffer. After the electrophoresis the developing TDA, pH 5.6, was poured onto the agar gel. The microscope slides were incubated at $37^{\circ} \mathrm{C}$ for $20 \mathrm{hrs}$.

Pancreas tissue, homogenized in equal amounts of saline, was treated in the same way as the intestinal contents. Zymograms of the pancreatic protein fraction, isolated as described for the protein fraction of PIC, were performed as outlined above.

\section{RESULTS}

The titres of DNases in PIC were regularly highest in the TDA medium, pH 5.6. Not only were the diameters of the pink circular zones greatest at that $\mathrm{pH}$, but also the distinction to the otherwise blue unchanged medium was more clearly seen. Fig. 1 shows the zones in TDA at different $\mathrm{pH}$ values for 3 representative samples. Fig. 2 shows the number of diffusion units of the same samples demonstrating the superiority of the TDA, pH 5.6, in comparison with other $\mathrm{pH}$ values in assaying DNases in intestinal contents. Controls showed no changes in the media employed. The TDA medium without $\mathrm{MgSO}_{4}$ incorporated revealed zone phenomena due to the presence of DNases. However, the number of diffusion units was significantly reduced as compared to the TDA medium containing $\mathrm{MgSO}_{4}$. In the TDA medium containing $2 \mathrm{M}-\mathrm{NaCl}$ no changes occurred.

Spectrophotometrically, the optimal conditions for measuring DNase activity in PIC were achieved when the enzymatic reaction was run at $\mathrm{pH}$ 7.2. When the enzymatic reaction was performed under acidic conditions the absorbance was usually insignificant as compared to pH 7.2 and $\mathrm{pH} 8$ (Fig. 2). However, in a few

* Difco Laboratories, Detroit, Michigan, USA. 


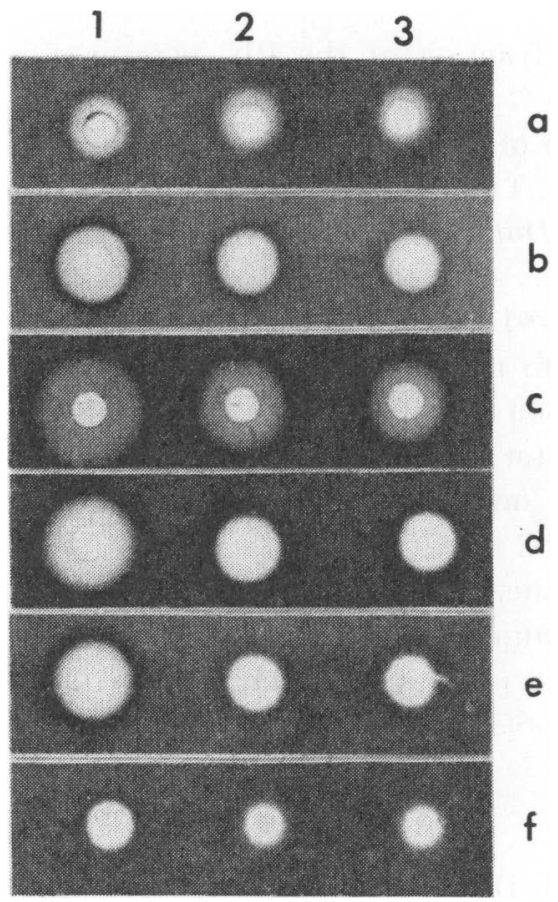

Figure 1. DNase activity on TDA of 3 representative samples $(1,2,3)$ at $\mathrm{pH} 4,5,5.6,7.2,8$ and $9(\mathrm{a}-\mathrm{f})$.

samples, a slight increase in DNase activity could be seen at pH 4. Particularly at pH 7.2 the supernatants frequently showed lower absorbances than they did when diluted 1:2. Fig. 2 also presents the absorbances of the diluted supernatants of 3 representative samples at different $\mathrm{pH}$ values.

Table 1. Comparison between ADT and spectrophotometry in assaying small concentrations of DNase activity. The figures represent the highest dilutions at which DNase could still be measured with the 2 methods involved, in 5 different samples.

\begin{tabular}{ccc}
\hline $\begin{array}{c}\text { Sample } \\
\text { number }\end{array}$ & $\begin{array}{c}\text { Spectrophotometry } \\
\text { at } \mathrm{pH} \mathrm{7.2}\end{array}$ & $\begin{array}{c}\text { Agar-diffusion } \\
\text { at } \mathrm{pH} 5.6\end{array}$ \\
\hline 1 & $1 / 4$ & $1 / 16$ \\
2 & $1 / 32$ & $1 / 32$ \\
2 & $1 / 64$ & $1 / 64$ \\
4 & $1 / 64$ & $1 / 128$ \\
5 & $1 / 256$ & $1 / 256$ \\
\hline
\end{tabular}




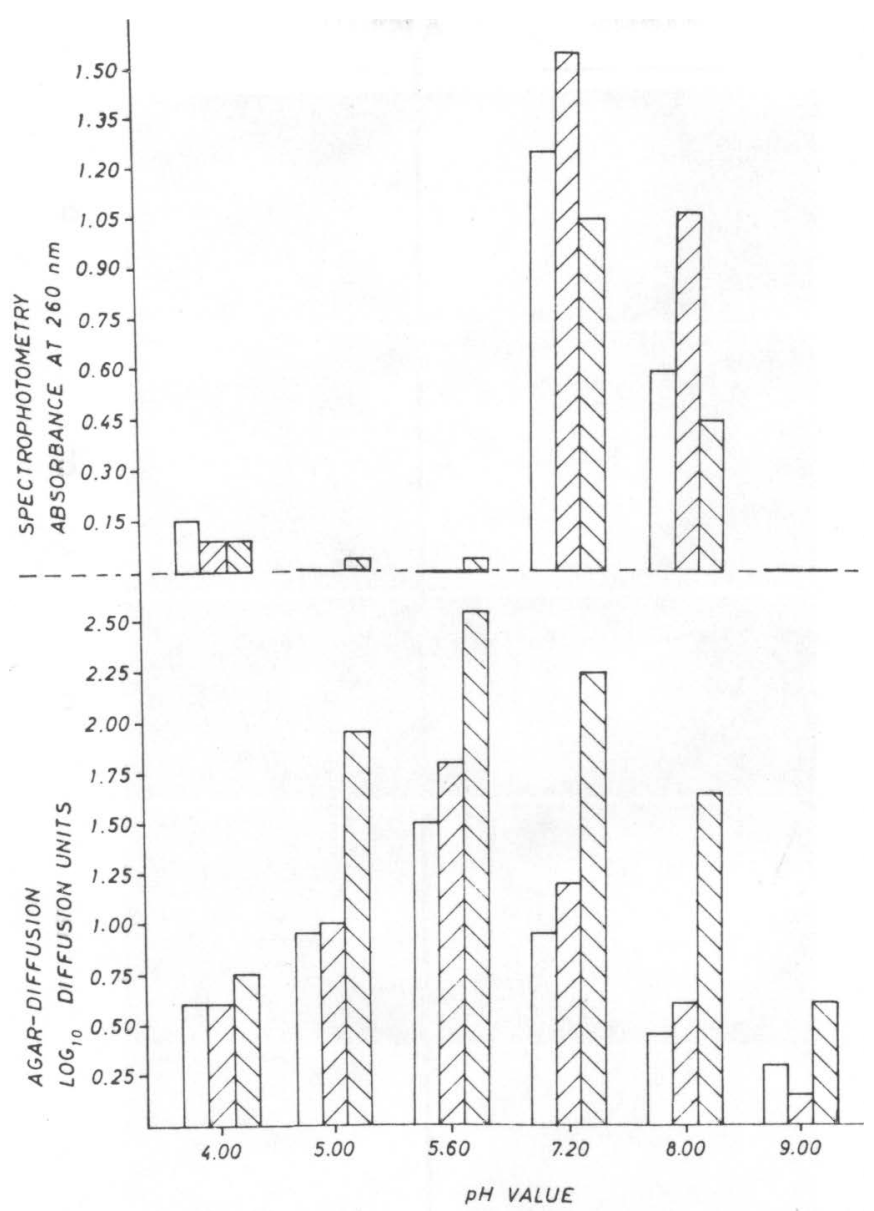

Figure 2. DNase activity at various $p H$ values in intestinal contents employing ADT and spectrophotometry, from 3 different samples.

(The same samples as in Fig. 1).

Following serial twofold dilutions of PIC, the 2 methods showed no significant differences in the ability to measure DNases at high dilutions of intestinal contents. Table 1 presents the dilutions at which initestinal DNases could still be measured in 5 different samples using spectrophotometry and ADT under optimal conditions.

Zymograms for DNases in intestinal contents are shown in Fig. 3. Three fractions of DNase activity can be distinguished. The most active fraction has anodic migration and is dominating 


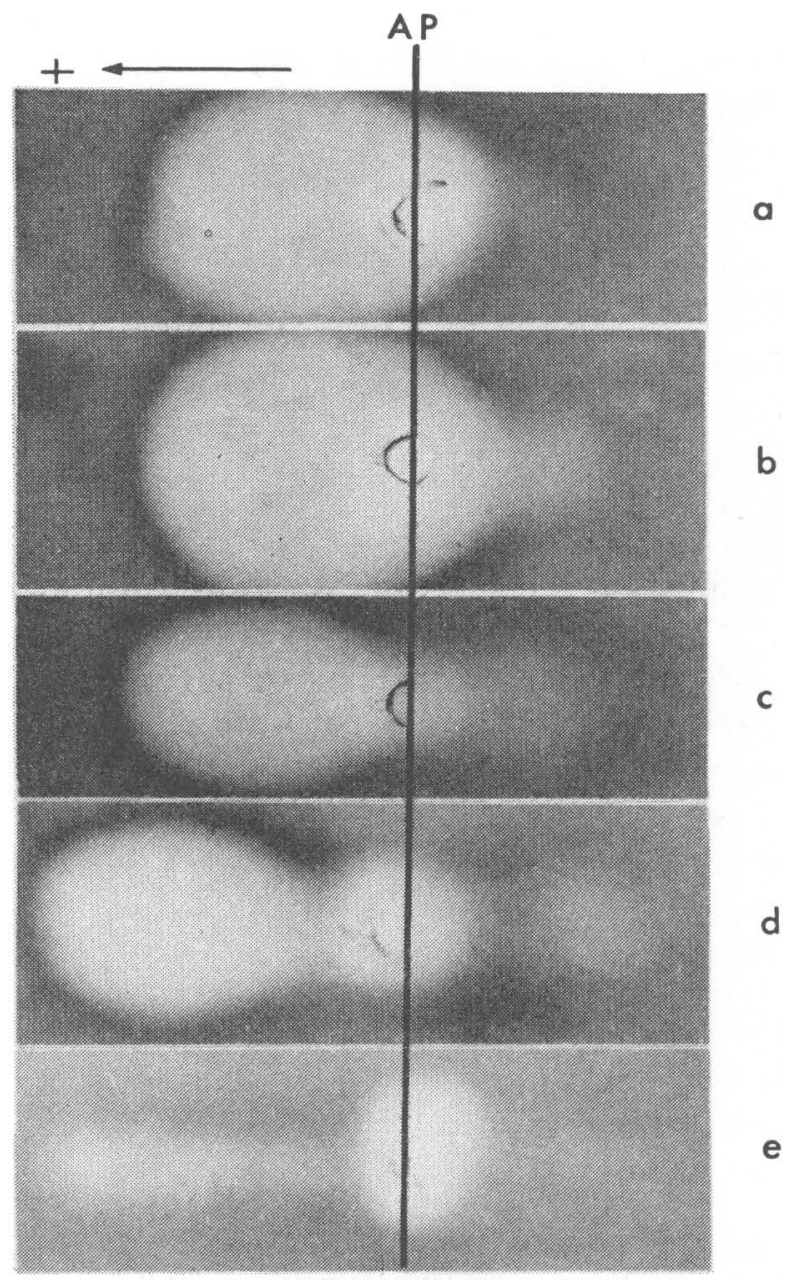

F i g u r e 3. Zymograms, in agar gel, of DNases from intestinal contents originating from a) upper, b) upper middle, c) lower middle, and d) lower small intestine and e) middle large intestine in 1 representative intestine.

in all parts of the intestine. In samples from the posterior part of the small intestine and from the large intestine, this fraction migrates faster than those from the other parts of the intestine. Another fraction is located at the point of application (AP), and is hardly separable in the 2 samples originating from the upper part of the small intestine. The less active fraction has cathodic migration and is more clearly separated in samples from the 
lower part of the small intestine and from the large intestine. Zymograms of the protein fraction of pancreas tissue revealed 1 active fraction with moderate anodic migration, and a second less active fraction at the point of application.

\section{DISCUSSION}

In the present investigation optimality in measuring intestinal DNases with the ADT is achieved at acidic conditions at $\mathrm{pH} \mathrm{5.6.}$ DNase activity can also be measured spectrophotometrically at an optimal $\mathrm{pH}$ of 7.2. Furthermore, 3 different DNases are distinguished in intestinal contents by the zymogram technique.

Allfrey \& Mirsky (1952) found that pancreatic juice contained high concentrations of "neutral" DNase, while the concentration of "acid" DNases was negligible. The DNase expected in intestinal content should therefore be of the first type. According to Laskowski (1961) the $\mathrm{pH}$ optimum of the neutral DNase lies close to pH 7.0 and is fairly broad, particularly on the acid side. It requires magnesium ions for activation and is inhibited by high concentrations of $\mathrm{NaCl}$. The optimal conditions for the “acid" DNase are pH 4.5 to 5.5. This enzyme is inhibited by magnesium ions and activated by sodium ions (Davidson 1965). The "neutral" DNase is called DNase I and the "acid" DNase is called DNase II.

In view of this a discrepancy exists with regard to the $\mathrm{pH}$ optimum for the 2 methods employed in the present work. However, because of the complete inactivation of DNases by high concentrations of $\mathrm{NaCl}$, the reduced number of diffusion units on TDA without $\mathrm{MgSO}_{4}$ incorporated, and the previously reported high concentrations of DNase $I$ in pancreatic juice, there seems to be good reasons to suggest that intestinal DNases measured with the ADT are mainly DNase I. The DNases observed on the TDA without $\mathrm{MgSO}_{4}$ is probably due to minute concentrations of magnesium ions, otherwise present in the medium, which may suffice to activate DNase I (Davidson), or the presence of other activating bivalent cations (Chargaff \& Davidson 1955). The possibility that the optimal conditions for the ADT in assaying DNase activity in intestinal contents may be found between $\mathrm{pH}$ 5.6 and 7.2 should also not be excluded. Oth et al. (1958) also observed that the pH optima obtained by different methods in assaying DNA splitting activity could differ strikingly. 
The moderate increase in DNase activity observed at $\mathrm{pH} 4.0$ in some samples, using the spectrophotometrical method, could be due to DNase II originating from the intestinal mucosa (Allfrey \& Mirsky). As reviewed by Laskowski, the activity of DNase II depends on series of factors which, under certain circumstances, may reduce the inhibitory effect of magnesium ions. The increased absorbance observed may, however, reflect the $\mathrm{pH}$ dependent absorbance of DNA products produced by DNase I. This indicates that the negligible absorbances observed when the enzymatic reaction was run at $\mathrm{pH} 5$ and $\mathrm{pH} 5.6$ do not reflect absence of DNase activity (Chargaff $\&$ Davidson). The decreased absorbances of the supernatants compared to those of their dilutions (1:2) may be due to the phenomenon of hypochromism, which includes reduced absorbance in relation to that which can be calculated (West et al. 1966). This would indicate that the base components produced by DNA splitting should be present in the diluted supernatants, at optimal conditions for the absorbance of the u.v.-radiation.

Comparing the sensitivity of the 2 methods employed in assaying DNases at high dilutions of intestinal contents no significant differences seem to exist. However, considering the small amounts of enzyme solution (PIC) used in the ADT $(0.05 \mathrm{ml})$ as compared to those in the spectrophotometrical method $(1 \mathrm{ml})$, there should be good reasons to nominate the ADT superior to the spectrophotometrical method for assaying intestinal DNases. Also the phenomenon, that the absorbance increases in dilution of the supernatants, further supports this.

It is relevant to discuss the origin of the 3 fractions showing DNase activity in intestinal content, revealed by the zymogram technique. Porschen \& Sonntag (1974) showed that DNase production by Gram-negative anaerobic bacteria usually found in intestinal content, was very common. Furthermore, DNases from plants and yeasts (Laskowski) should be expected in the intestinal tract of pigs fed on ordinary diets. These DNases are similar to DNase I present in the pancreatic juice with regard to requirements and pH optima. Consequently, it may be expected that DNase activity in intestinal contents, to some extent, can be due to extra-pancreatic enzyme production. The comparison between the zymograms of the protein fractions of intestinal contents and pancreas tissue also gives evidence that the fraction with cathodic migration is probably of non-pancreatic origin. 
In conclusion the ADT employed in these experiments seems suitable for assaying DNase activity in intestinal contents. No difficulties with the procedure described have occurred in spite of the very crude and heterogenous material used. Advantage will be taken of this in future feeding experiments with diets composed of single cell proteins where the effect of the high amounts of substrate (DNA in single cell protein) upon the concentration of DNases in the intestine will be examined.

\section{REFERENCES}

Allfrey, V. \& A. E. Mirsky: Some aspects of the deoxyribonuclease activities of animal tissues. J. gen. Physiol. 1952, 36, 227-241.

Chargaff, E. \& J. N. Davidson: The Nucleic Acids. Vol. I. Acad. Press Inc., New York 1955.

Dahle, $H . K .:$ Quantitative assay of a single proteolytic enzyme in a crude mixture of bacterial proteinases. Acta path. microbiol. scand. 1969, 77, 134-142.

Dahle, H. K.: Zymograms in agar gel of some animal and bacterial proteinases. Acta path. microbiol. scand. Section B. 1970, 78, 575578.

Davidson, J. N.: Nucleases and related enzymes. In Davidson, J. N.: The Biochemistry of the Nucleic Acids. 5th Ed. Methuen \& Co. Ltd., John Wiley \& Sons, Inc. London and New York 1965, 81-96.

Kihlberg, R.: The microbe as a source of food. Ann. Rev. Microbiol. $1972,26,427-466$.

Lachica, R. V. F., C. Genigeorgis \& P. D. Hoeprich: Metachromatic agar-diffusion methods for detecting staphylococcal nuclease activity. Appl. Microbiol. 1971, 21, 585-587.

Laskowski, SR. M.: The Enzymes. 2nd Ed., 5, Acad. Press Inc., New York and London 1961, 123-147.

Liven, E.: Deoxyribonuclease production by leptospires. Acta vet. scand. 1975, 16, 477-479.

McDonald, M. R.: Methods in Enzymology. 2. Acad. Press Inc., New York 1955, 437-438.

Oth, A., E. Fredericq \& R. Hacha: Enzymatic degradation of deoxyribonucleic acid. II. Enzymatic properties of thymus acid deoxyribonuclease. Biochim. biophys. Acta (Amst.) 1958, 29, 287-296.

Porschen, R. K. \& S. Sonntag: Extracellular deoxyribonuclease production by anaerobic bacteria. Appl. Microbiol. 1974, 27, 10311033.

Sandvik, O.: Studies on Casein Precipitating Enzymes of Aerobic and Facultatively Anaerobic Bacteria. Thesis. Veterinary College of Norway, Oslo 1962, 116 pp. 
Sandvik, O.: The occurrence of antibodies against staphylococcal deoxyribonucleases in blood sera from different species. Acta vet. scand. $1974,15,631-635$.

West, E. D., W. R. Todd, H. S. Mason \& J. T. van Bruggen: Textbook of Biochemistry. 4th Ed. The Macmillian Company. New York and London 1966.

\section{SAMMENDRAG}

Anvendelighet av agar-diffusjonstest ved måling av deoxyribonukleaser $i$ tarminnhold hos gris.

Det er blitt unders $\varnothing$ kt om en agar-diffusjonstest (ADT) kan anvendes til å måle DNase aktiviteten i tarminnhold hos gris. ADT ble sammenlignet med en spektrofotometrisk metode. I agaren som inneholdt DNA, ble det laget brønner som ble fylt med tarminnhold og rundt disse fremkom metakromatiske soner som indikasjon på DNase aktivitet. Ved 2-folds fortynning av tarminnholdet kunne ADT nyttes for semikvantitativ bestemmelse av DNase aktiviteten. ADT var mest sensitiv ved $\mathrm{pH} 5,6$. Ved hjelp av de 2 metoder kunne en påvise om lag like lave konsentrasjoner av DNase. ADT ble likevel ansett for mer hensiktsmessig enn den spektrofotometriske metode fordi det ved ADT ble målt mindre mengder enzym. DNase aktivitet ble påvist i hele tynntarmen samt i tykktarmen. Ved bruk av zymogramteknikk ble det påvist 3 forskjellige DNaser $i$ de nedre deler av tynntarmen hvorav en kan ha annen opprinnelse enn pankreas.

(Received March 26, 1976).

Reprints may be requested from: Eivind Liven, the Department of Microbiology and Immunology, Veterinary College of Norway, Postbox 8146, Oslo Dep., Oslo 1, Norway. 